\title{
A food tourism textbook served in four courses
}

\author{
Review by Lisa Chase*
}

Review of Food and Agricultural Tourism: Theory and Best Practice, by Susan L. Slocum \& Kynda R. Curtis. (2017). London: Routledge. Available as hardcover, paperback, and ebook; 262 pages. https://doi.org/10.4324/9781315679945

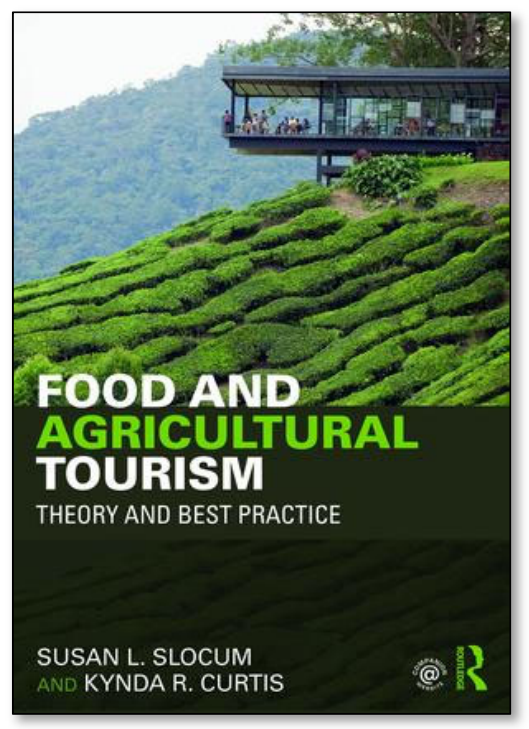

Submitted December 9, 2018 / Published online April 30, 2019

Citation: Chase, L. (2019). A food tourism textbook served in four courses [Book review]. Journal of Agriculture, Food Systems, and Community Development. 119-121. https://doi.org/10.5304/jafscd.2019.091.001

Copyright (C) 2019 by the Author. Published by the Lyson Center for Civic Agriculture and Food Systems. Open access under CC-BY license.

$I_{1}$ was packing my suitcase to fly to Italy for the $1^{\text {st }}$ World Congress on Agritourism when a large brown envelope showed up in my mailbox. I ripped open the package to find Susan L. Slocum and Kynda R. Curtis's new textbook, Food and Agricultural Tourism: Theory and Best Practice. Perfect reading for my flight to Europe!

Flying over the Atlantic Ocean, I flipped through the book and was immediately drawn in by the colorful case studies of food tourism around the world. The study questions for students had me hooked: How would you define authentic food from your area? How does globalization lead to specialization in agricultural production? What does "rice for life" mean? How can the Rattlesnake

* Lisa Chase is the natural resources specialist for University of Vermont Extension and director of the Vermont Tourism Research Center. Her research and outreach focus on the intersection of food systems, community vitality, and working landscapes. She and Vern Grubinger co-authored the book Food, Farms and Community: Exploring Food Systems (see the JAFSCD review). She can be reached at Lisa.Chase@uvm.edu.
Hills Wine Trail enhance the visitor experience?

Slocum and Curtis explore these questions and many more in their well-written and well-organized textbook for college students. Professors seeking textbooks for their courses will appreciate the layout of the book, where each chapter begins with an overview, followed by a list of learning objectives. The meat of the chapter is presented in sections with clear headings, illustrated with relevant images, figures, and tables. Each chapter ends with a summary, study questions, and definitions. The final touch is a case study or two for each chapter, located just before the chapter's reference list. These compelling case studies include images and end with questions for students to ponder.

The book is divided into four parts. Part I focuses on food tourism and sustainable rural development, with chapters on (1) tourism, agriculture, and rural economic development; (2) food tourism and sustainable communities; and (3) food tourism offerings. These three chapters lay the groundwork for the rest of the book. Chapter 1 
provides background on the key industries of tourism, agriculture, and rural development and introduces several terms related to the study of economic impacts. Chapter 2 delves into sustainable tourism and presents a balanced discussion on its many benefits for communities while also acknowledging some of the associated challenges. Chapter 3 addresses agritourism, culinary tourism, food trails, events, and the importance of authenticity.

Part II describes the evolution of agriculture and the importance of food in contemporary culture. This section tackles topics such as globalizing agriculture to feed the world; rural landscapes, heritage, and economic development; and modern food movements. Chapter 4 lays out two centuries of historical background on the industrialization of agriculture, along with its caveats for consumers. Chapter 5 discusses the impacts of rural migration of families and youth to urban centers. Food tourism is presented as a strategy to revitalize rural communities. Chapter 6 focuses on three current food movements: buy local, foodie, and sustainable consumption. These food movements provide opportunities for rural economic development, which are detailed in Part III.

Part III examines food tourism markets and targeted destination design. Chapters explore food tourists and food tourism markets, as well as the process for developing a food tourism destination. Chapter 7 presents research on general traveler typologies, including so-called foodies and food tourists. Chapter 8 emphasizes the importance of identifying target markets and summarizes methods for market research. Chapter 9 details brand development and strategies to market destinations. These three chapters will be of interest to practitioners as well as faculty and students.

The final section, Part IV, concentrates on food tourism policy and practice, and includes chapters on policy and governance, safety in food tourism operations, and devising the food tourism product. Chapter 10 discusses good governance and policy cycles, and explores how they affect food tourism in both positive and negative ways. Chapter 11 focuses on food safety. While this is an important topic, the chapter is written by a contributing author (Karin Allen, Curtis's colleague at Utah State University), bringing in a new voice but slightly interrupting the flow of the text. Chapter 12 concludes the book with practical tools for developing business and marketing plans, including financial feasibility assessment and breakeven pricing.

If you were to guess that this textbook has a lot of economics in it, you'd be correct. I suspect that is due to Curtis's influence, as she has a Ph.D. in economics and is a professor and Extension specialist in agriculture and food marketing in the Department of Applied Economics at Utah State University. The emphasis on economics is balanced by Slocum's background in sustainable rural development, policy implementation, and food tourism. She is an assistant professor in the Department of Tourism and Event Management at George Mason University. Both authors have traveled extensively, resulting in case studies and examples from all over the world. Many of the case studies were written by the authors, although some were contributed by others.

Publication of this textbook is aptly timed, as university programs in food systems are growing worldwide, along with interest in food tourism and agritourism. For instance, CABI has a new series on tourism that includes Food and Wine Tourism: Integrating Food, Travel and Terroir, by Croce and Meridies, and Food Tourism: A Practical Marketing Guide, by Stanley and Stanley. Slocum and Curtis's book was written as a textbook first and foremost, although it could be useful for practitioners. The books from CABI were primarily written for practitioners but could be used in the classroom. While all three books seek to cover the world, the countries emphasized in the case studies vary somewhat.

Slocum and Curtis's book is an important contribution to the literature, and I have no doubt it will be widely used by faculty and students working at the intersection of agriculture, tourism, and rural economic development. Faculty considering developing a course on food tourism need look no further. This textbook can serve as the framework for a semester-long course. The book can also complement existing syllabi that focus on broader issues related to food and agricultural tourism. I will not be surprised to find this book — with its relevant case studies and 
practical advice related to policy, governance, and development of a food tourism destination-on practitioners' shelves as well.

As advertised, this textbook "fills a gap in the growing academic discipline of food and agricultural tourism." That gap, however, is extremely large, and the authors can continue to add value by helping to build the community of faculty, students, and practitioners who will use the book. This book has a companion website ${ }^{1}$ with online quizzes for each chapter and resources for instructors. The rapidly growing field of food and agricultural tourism will surely benefit from Slocum and Curtis's textbook, along with complementary efforts to support this emerging community of practice.

1 The companion website is at https://www.routledgetextbooks.com/textbooks/9781138931107/default.php 